\title{
Reduction of the subcooling of bischofite with the use of nucleatings agents
}

\author{
Svetlana Ushak ${ }^{1,2,{ }^{*}}$, Andrea Gutierrez ${ }^{1}$, Camila Barreneche ${ }^{3,4}$, A. Inés Fernandez ${ }^{3}$, Mario Grágeda ${ }^{1,2}$, \\ Luisa F. Cabeza ${ }^{4}$ \\ ${ }^{1}$ Department of Chemical Engineering and Mineral Processing and Center for Advanced Study of Lithium and Industrial \\ Minerals (CELiMIN), Universidad de Antofagasta, Campus Coloso, Av. Universidad de Antofagasta 02800, Antofagasta, \\ Chile. \\ ${ }^{2}$ Solar Energy Research Center (SERC-Chile), Av Tupper 2007, Piso 4, Santiago, Chile \\ ${ }^{3}$ Department of Materials Science and Metallurgical Engineering, Universitat de Barcelona, Martí i Franqués 1, 08028 \\ Barcelona, Spain \\ ${ }^{4}$ GREA Innovació Concurrent, Universitat de Lleida, Edifici CREA, Pere de Cabrera s/n, 25001, Lleida, Spain \\ *corresponding author: svetlana.ushak@uantof.cl
}

\begin{abstract}
The use of by-products or wastes as phase change materials (PCM) in thermal energy storage (TES) systems is a good option to decrease the cost of such systems. One of the main disadvantages of PCM if inorganic materials are used is subcooling, as was found with bischofite, a by-product from the Chilean non-metallic industry, which subcooling is about $36^{\circ} \mathrm{C}$. Subcooling can be reduced by the addition of nucleating agents, but the selection of the best nucleating agent should be done taking into consideration the physical and chemical parameters of the salt hydrate. In this paper the parameters considered were the solubility of the materials in water, the chemical structure and the crystalline structure (crystal system, lattice parameters, density, cell volume, $Z$, and space group). It could be concluded that solubility, chemical structure and the crystal structure have no influence in the nucleation capacity of a salt hydrate. The parameter that needs to be considered when selecting a nucleating agent for a salt hydrate is the lattice parameters of the crystal structure (cell longitude or angle).
\end{abstract}

Key-words: phase change material (PCM); thermal energy storage (TES); subcooling; nucleation agent; bischofite

\section{Introduction}

Looking for new thermal energy storage (TES) materials for latent heat energy storage with lower costs to those available today has brought researchers to study waste materials or by-products from the industry $[1,2]$. Such new phase change materials (PCM), as they are known, should have better performance or at least the expected thermal and chemical stability for PCM. Ushak 2015 [1] showed that bischofite, a by-product from the non-metallic industry in the production of potassium chloride in Solar the Atacama (Chile), has a good potential to be used in TES as PCM if its subcooling is reduced. The properties determined are presented in Table 1. 
Table 1. Thermophysical properties of bischofite and $\mathrm{MgCl}_{2} \cdot 6 \mathrm{H}_{2} \mathrm{O}$ [1].

\begin{tabular}{|c|c|c|c|c|c|c|c|}
\hline Sample & Cycle no. & $\mathrm{T}_{\mathrm{F}}[\mathrm{o} \mathrm{C}]$ & $\Delta H_{F}[\mathrm{~J} / \mathrm{g}]$ & $\mathrm{T}_{\mathrm{C}}[\stackrel{\circ}{\mathrm{C}}]$ & $\Delta \mathrm{H}_{\mathrm{c}}[\mathrm{J} / \mathrm{g}]$ & $\begin{array}{l}\text { Subcooling } \\
\text { [OC ] }\end{array}$ & $\begin{array}{l}\text { Storage } \\
\text { energy } \\
\text { density } \\
{\left[\mathrm{J} / \mathrm{cm}^{3}\right]}\end{array}$ \\
\hline \multirow[t]{3}{*}{ Bischofite } & 10 & 100.9 & 116.2 & 65.4 & 115.2 & 35.5 & \multirow[t]{3}{*}{170} \\
\hline & 20 & 101.1 & 116.0 & 70.1 & 115.5 & 31.0 & \\
\hline & 30 & 102.2 & 115.5 & 58.7 & 115.8 & 43.5 & \\
\hline \multirow[t]{3}{*}{$\mathrm{MgCl}_{2} \cdot 6 \mathrm{H}_{2} \mathrm{O}$} & 10 & 114.5 & 133.5 & 88.8 & 129.5 & 25.7 & \multirow[t]{3}{*}{192} \\
\hline & 20 & 114.6 & 133.1 & 83.2 & 129.4 & 31.4 & \\
\hline & 30 & 114.4 & 136.9 & 85.2 & 132.3 & 29.2 & \\
\hline
\end{tabular}

Subcooling (also called supercooling or undercooling) means that a liquid can be cooled below its melting point without causing crystallization. As Huang et al. 2010 [3] state, this effect is not desired in latent heat storages because it will enlarge the operating temperature range of the systems, and in some cases it will disable the use of a given material as PCM. Cabeza et al. 2011 [4] listed several approximations used to solve this problem; the use of the PCM in direct contact heat transfer between an immiscible heat transfer fluid and the PCM and the use of nucleation agents. The first review to list nucleation agents appeared in 1991 [5].

The scope of this paper is to select the best nucleating agent to be used with bischofite in order to optimize its performance as phase change material by reducing its subcooling. Due to the chemical composition of bischofite $\left(95 \% \mathrm{MgCl}_{2} \cdot 6 \mathrm{H}_{2} \mathrm{O}\right)$ [1], the study is done in parallel with the two PCM (bischofite and $\mathrm{MgCl}_{2} \cdot 6 \mathrm{H}_{2} \mathrm{O}$ ). Moreover, since the use of nucleating agents for $\mathrm{MgCl}_{2} \cdot 6 \mathrm{H}_{2} \mathrm{O}$ to reduce its subcooling was carried out by Pilar et al. 2012 [6], this work was taken as starting point.

Following this scope, the parameters and factors that have been listed in the literature to have influence in the selection of a nucleation agents were taken into consideration and were compared to the results obtained to corroborate their influence. The factors considered were the solubility of the materials in water, the chemical structure and the crystalline structure (crystal system, lattice parameters, density, cell volume, $Z$, and space group).

\section{Nucleating agents selection}

The main nucleating agents are those that will have stable structure and stable state under the working conditions with crystallographic parameters close and similar to the material under study (in this case bischofite). There are several criteria to classify and select the proper nucleating agent for each material as has been previously reported by other authors [5,7-9]:

- Homogeneous nucleation, also named chemical nucleation, happens when the nucleating agent changes the phase very similarly than the salt hydrate; within this self-nucleation is when solid crystals of the original salt hydrate are introduced to help the melting process.

- Heterogeneous nucleation, also known as physical nucleation, is produced when the nucleating agent remains solid while the salt hydrate melts. Within this type, one can find isomorphous or partly-isomorphous nucleation, when the nucleating agents have the same morphology than 
the salt hydrate under phase change but the nucleating agents do not distort the melting temperature of the salt hydrate either the phase change enthalpy; isotypic nucleation, when the nucleating agent is the same substance as the salt under study but has different crystallographic phase, therefore it does not change the phase under the working temperature; and epitaxial nucleation, when the nucleating agents must be partly similar to the crystal form of the salt under study as well as lattice spacing and atomic arrangement with a range of $15 \%$.

This classification is summarized in Table 2.

Table 2. Classification of nucleating agents

\begin{tabular}{|l|c|c|c|c|}
\hline Method & Self-nucleation & \multicolumn{2}{|c|}{ Scientific } & Edisodian \\
\hline $\begin{array}{l}\text { Classes of nucleating } \\
\text { agents }\end{array}$ & Same material & Isomorphus & Isotypic & Epitaxial \\
\hline Chemical Structure & $\mathrm{X}$ & $\mathrm{X}$ & - & - \\
\hline Crystal structure & $\mathrm{X}$ & $\mathrm{X}$ & $\mathrm{X}$ & - \\
\hline Lattice Parameters & $\mathrm{X}$ & $\mathrm{X}$ & $\mathrm{X}$ & $\mathrm{X}$ \\
\hline
\end{tabular}

In this study, some candidates based on literature $[5,6]$ were chosen to be used as nucleating agents for bischofite; $\mathrm{SrCO}_{3}, \mathrm{Sr}(\mathrm{OH})_{2}, \mathrm{Mg}(\mathrm{OH})_{2}, \mathrm{LiOH} \cdot \mathrm{H}_{2} \mathrm{O}, \mathrm{LiC}_{2} \mathrm{O}_{3}, \mathrm{CaO}, \mathrm{Ca}(\mathrm{OH})_{2}, \mathrm{MgCl}_{2} \cdot 6 \mathrm{H}_{2} \mathrm{O}$. Their crystallographic parameters were obtained from different databases and they are shown in Table 3. From this table, five nucleating agents were selected; $\mathrm{Li}_{2} \mathrm{CO}_{3}$ and $\mathrm{LiOH} \cdot \mathrm{H}_{2} \mathrm{O}$ were chosen because of their crystal system, which is the same of bischofite and synthetic $\mathrm{MgCl}_{2} \cdot 6 \mathrm{H}_{2} \mathrm{O}$. The other three nucleating agents, $\mathrm{SrCO}_{3}, \mathrm{Sr}(\mathrm{OH})_{2}$ and $\mathrm{CaO}$ were chosen based on successful results reported by other authors $[5,6]$. 
Table 3. Crystallographic parameters from the literature of the PCM and nucleating agents considered in this study.

\begin{tabular}{|c|c|c|c|c|c|c|c|c|c|c|c|c|c|c|}
\hline $\begin{array}{l}\text { Chemical } \\
\text { Formula }\end{array}$ & $\begin{array}{l}\text { Crystal } \\
\text { system }\end{array}$ & a $(\AA)$ & b (Å) & $c(\AA)$ & Alpha & Beta & Gamma & $\begin{array}{l}\text { Density }{ }_{\text {calc }} \\
\left(\mathrm{g} \mathrm{cm}^{-3}\right)\end{array}$ & $\begin{array}{l}\text { Density } \\
\left(\mathrm{g} \mathrm{cm}^{-3}\right)\end{array}$ & $\begin{array}{l}V_{\text {cell }} \\
\left(10^{6}\right. \\
\left.\mathrm{pm}^{3}\right)\end{array}$ & $\mathbf{Z}$ & $\begin{array}{l}\text { Space } \\
\text { Group }\end{array}$ & $\begin{array}{l}\text { Space } \\
\text { group } \\
\text { number }\end{array}$ & References \\
\hline $\begin{array}{l}\text { Bischofite } \\
\left(\mathrm{MgCl}_{2} \cdot 6 \mathrm{H}_{2} \mathrm{O}\right)\end{array}$ & Monoclinic & 9.900 & 7.150 & 6.100 & 90.000 & 94.000 & 90.000 & - & 1.56 & 430.74 & 2 & $\mathrm{C} 2 / \mathrm{m}$ & 12 & $\begin{array}{l}\text { Ushak et al. } \\
2015 \text { [1] }\end{array}$ \\
\hline $\mathrm{MgCl}_{2} \cdot 6 \mathrm{H}_{2} \mathrm{O}$ & Monoclinic & 9.861 & 7.107 & 6.074 & 90.000 & 93.758 & 90.000 & 1.5895 & 1.5930 & 424.74 & 2 & $\mathrm{C} 2 / \mathrm{m}$ & - & $\begin{array}{l}\text { Agron and } \\
\text { Busing } 1985 \\
{[10]}\end{array}$ \\
\hline \multirow[t]{2}{*}{$\mathrm{Ca}(\mathrm{OH})_{2}$} & Hexagonal & 3.590 & 3.590 & 4.916 & 90.000 & 90.000 & 120.000 & - & 2.24 & 54.87 & 1 & P-3m1 & 164 & $\begin{array}{l}\text { Martin and } \\
\text { McCarthy } 1992 \\
{[11]}\end{array}$ \\
\hline & Hexagonal & 3.585 & 3.585 & 4.895 & 90.000 & 90.000 & 120.000 & 2.26 & - & 54.49 & 1 & P-3m1 & 164 & $\begin{array}{l}\text { Petch } 1961 \\
{[12]}\end{array}$ \\
\hline \multirow[t]{3}{*}{$\mathrm{Li}_{2} \mathrm{CO}_{3}$} & Monoclinic & 8.390 & 5.000 & 6.210 & 90.000 & 114.500 & 90.000 & 2.07 & 2.09 & 237.05 & 4 & $\mathrm{C} 2 / \mathrm{c}$ & 15 & $\begin{array}{l}\text { Zemann } 1957 \\
{[13], \text { and }} \\
\text { Mallard } 1892 \\
{[14]}\end{array}$ \\
\hline & Monoclinic & --- & --- & --- & --- & --- & --- & --- & 2.11 & --- & - & - & 15 & $\begin{array}{l}\text { Hanawalt et al. } \\
1938[15]\end{array}$ \\
\hline & Monoclinic & 8.359 & 4.972 & 6.198 & 90.000 & 114.830 & 90.000 & 2.10 & 2.09 & 233.80 & 4 & $\mathrm{C} 2 / \mathrm{c}$ & 15 & $\begin{array}{l}\text { Effenberger et } \\
\text { al. 1979 [16] }\end{array}$ \\
\hline $\mathrm{LiOH} \cdot \mathrm{H}_{2} \mathrm{O}$ & Monoclinic & 7.415 & 8.305 & 3.195 & 90.000 & 110.107 & 90.000 & 1.51 & - & 184.78 & 4 & $\mathrm{C} 2 / \mathrm{m}$ & 12 & $\begin{array}{l}\text { Hermansson } \\
1982[17]\end{array}$ \\
\hline $\mathrm{Sr}(\mathrm{OH})_{2}$ & $\begin{array}{l}\text { Orthorhombi } \\
\text { c }\end{array}$ & 9.989 & 6.120 & 3.918 & 90.000 & 90.000 & 90.000 & 3.41 & - & 237.15 & 4 & Pnam & 62 & $\begin{array}{l}\text { Baernighausen } \\
\text { et al. } 1969 \text { [18] }\end{array}$ \\
\hline \multirow[t]{3}{*}{$\mathrm{SrCO}_{3}$} & $\begin{array}{l}\text { Orthorhombi } \\
\text { c }\end{array}$ & 5.090 & 8.358 & 5.997 & 90.000 & 90.000 & 90.000 & 3.84 & - & 255.13 & 4 & Pmcn & 62 & $\begin{array}{l}\text { De Villiers } 1971 \\
{[19]}\end{array}$ \\
\hline & $\begin{array}{l}\text { Rhombohedr } \\
\text { al }\end{array}$ & 5.092 & 5.092 & 9.530 & 90.000 & 90.000 & 120.000 & 3.44 & - & 213.99 & 3 & $\mathrm{R}-3 \mathrm{~m}$ & 166 & $\begin{array}{l}\text { Stromme } 1975 \\
{[20]}\end{array}$ \\
\hline & $\begin{array}{l}\text { Orthorhombi } \\
\text { c }\end{array}$ & 5.104 & 8.402 & 6.022 & 90.000 & 90.000 & 90.000 & 3.80 & - & 258.25 & 4 & Pmcn & 62 & $\begin{array}{l}\text { Jarosch and } \\
\text { Heger } 1988 \\
{[21]}\end{array}$ \\
\hline
\end{tabular}




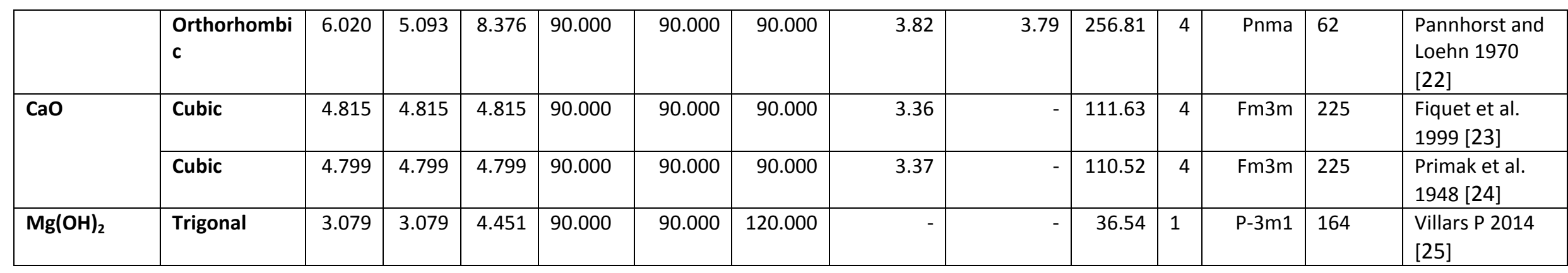




\section{Materials and Methods}

\subsection{Materials}

Bischofite $\left(>95 \% \mathrm{MgCl}_{2} \cdot 6 \mathrm{H}_{2} \mathrm{O}\right.$ ) was obtained in different times of a year from solar brine evaporation ponds, during the process to obtain $\mathrm{Li}_{2} \mathrm{CO}_{3}$ and $\mathrm{KCl}$ in the Atacama Salt flat. All the samples were homogenized and divided to their respective study. Synthetic nucleating agents were obtained from different suppliers: $\mathrm{LiOH} \cdot \mathrm{H}_{2} \mathrm{O}$ (ACS, 98\% min- Alfa Aesar), $\mathrm{Li}_{2} \mathrm{CO}_{3}$ and $\mathrm{SrCO}_{3}$, from Alfa Aesar $\mathrm{Sr}(\mathrm{OH})_{2}$ (Aldrich Chemistry), $\mathrm{CaO}$ (99.95\% (metal basis)- Alfa Aesar).

\subsection{Analytical methods}

The solubility data were obtained from literature reported by Linke and Seidell [26]. An extensive literature review was done to obtain crystallographic parameters of nucleating agents and as some of them have more than one crystallographic structure (Table 3), X-ray diffraction (XRD) was performed. An x-ray diffraction spectrum was obtained with a Bragg-Brentano Siemens D-500 powder diffractometer with $\mathrm{Cu} K \alpha$ radiation. Starting $2 \theta$ angle was $4^{\circ}$ and the final $2 \theta$ angle was $70^{\circ}$, respectively, and the measuring time was $3 \mathrm{~s}$ per step. Based on these results and comparing those with patterns available in X'pert high Score plus data-base, the crystallographic forms of the nucleating agents were identified. Moreover, using Diamond [27] unit cell structure of each nucleating agent was drawn.

A complete thermophysical characterization of the samples including the nucleating agents was carried out. The equipment used to perform the DSC analysis was a DSC-822e commercialized by Mettler Toledo. The amount of sample analyzed was around $10 \mathrm{mg}$ inside $40 \mu \mathrm{L}$ aluminum crucibles under $\mathrm{N}_{2}$ atmosphere flow of $80 \mathrm{~mL} \mathrm{~min}{ }^{-1}$. A dynamic mode from $25^{\circ} \mathrm{C}$ to $120^{\circ} \mathrm{C}$ was applied using a $0.5^{\circ} \mathrm{C} \mathrm{min}^{-1}$ heating/cooling rate to perform the thermal characterization by DSC.

\subsection{Experimental method (DoE)}

Nowadays statistics have achieved scientific methods that are useful for application in different experimental scenarios. These methods are known as design of experiments (DoE). Experimentally, the use of DoE reduces errors; time, and optimizes the number of experiments. Using a minimum number of experiments, maximum information can be obtained. In this paper, the selected design of experiments was a response surface three level factorial plan for two variables and the experimental plan was performed and analyzed with the "Design-Expert 7.0" software. The concentration of nucleating agent was varied between $0.5 \%$ wt. and $3 \%$ wt. The performance of the mixture formulation followed a random order to minimize systematic and cumulative errors on the results. The analysis of DoE results was performed using the analysis of variance (ANOVA) $[28,29]$. In this case, $p$ and $F$ values have been used to interpret the obtained results. The $p$-value indicates whether the factor has a significant contribution to the model, represents the smallest level of significance that would lead to rejection of the null-hypothesis while this hypothesis is true. A p-value lower than the level of significance $(\alpha=0.05)$ indicates significant contribution of the factor with a $95 \%$ of confidence. The F-value is defined as the ratio of the Model SS / Residual SS (Model SS and residual SS referred to the regression and error sum of squares respectively). Large F-values indicate significant contribution while small values denote that the variance could be affected by noise. 
The evaluated response was the evaluation of the sample subcooling by applying for the lowest subcooling. The subcooling was evaluated by the thermophysical properties measured with the DSC mention above.

\section{Results}

\subsection{Selection Parameters}

\subsubsection{Solubility of materials}

Figure 1 shows the solubility of $\mathrm{MgCl}_{2} \cdot 6 \mathrm{H}_{2} \mathrm{O}$ and the considered nucleating agents in water. While $\mathrm{LiOH} \cdot \mathrm{H}_{2} \mathrm{O}$ has a solubility higher than the PCM, all other considered nucleating agents is much lower.

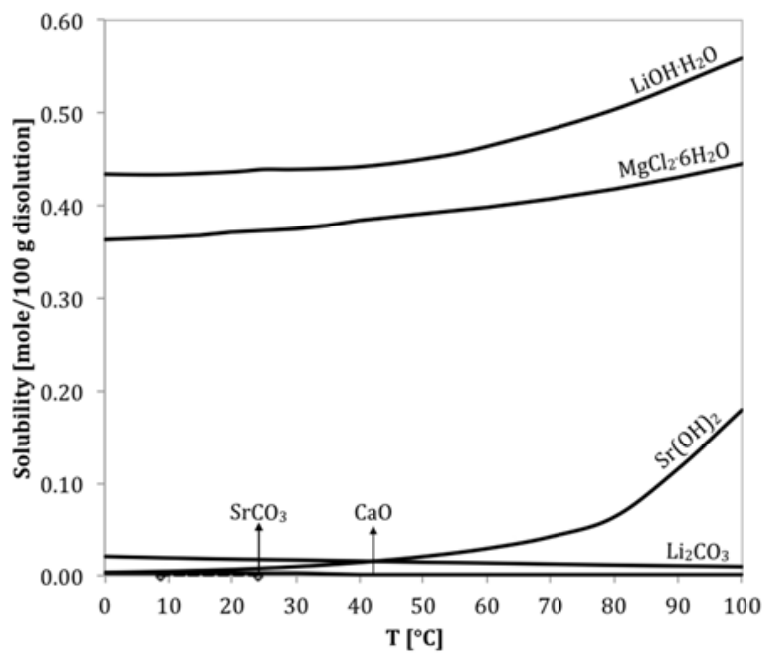

Figure 1. Solubility of magnesium chloride hexahydrate and nucleating agents in water.

\subsubsection{Crystal structure of materials}

Crystallographic parameters obtained from the data base showed that some salts hydrates present more than one crystallographic structure. In order to be sure about the crystallographic parameters of the salt hydrates studied, these were determined by XRD. Results obtained are presented in Table 4 and unit cell for each component were drawn and are shown in Figure 2 (these drawings allow identifying the structural similarities and differences between bischofite and nucleating agents). It can be seen that as expected bischofite and synthetic $\mathrm{MgCl}_{2} \cdot 6 \mathrm{H}_{2} \mathrm{O}$ have almost the same crystallographic parameters. The nucleating agents $\mathrm{Li}_{2} \mathrm{CO}_{3}$ and $\mathrm{LiOH} \cdot \mathrm{H}_{2} \mathrm{O}$ have monoclinic crystal system, just as bischofite and synthetic $\mathrm{MgCl}_{2} \cdot 6 \mathrm{H}_{2} \mathrm{O}$. However, $\mathrm{Sr}(\mathrm{OH})_{2}$ and $\mathrm{SrCO}_{3}$ have more similar unit cells dimensions ( $a, b, c$ ) and angles (Alpha, Beta, Gamma) to bischofite and $\mathrm{MgCl}_{2} \cdot 6 \mathrm{H}_{2} \mathrm{O}$ than the rest of nucleating agents, but their crystal system are orthorhombic. Finally, even though the angles of $\mathrm{CaO}$ are similar to bischofite and synthetic $\mathrm{MgCl}_{2} \cdot 6 \mathrm{H}_{2} \mathrm{O}$, unit cell dimensions are significantly different. 
Table 4. Crystallographic parameters of bischofite and nucleating agents measured by the authors.

\begin{tabular}{|c|c|c|c|c|c|c|c|c|c|c|c|c|}
\hline $\begin{array}{l}\text { Chemical } \\
\text { formula }\end{array}$ & Crystal system & a $(\AA)$ & b (Å) & c (Å) & Alpha & Beta & Gamma & $\begin{array}{l}\text { Calculated } \\
\text { density } \\
\left(\mathrm{g} \mathrm{cm}^{-3}\right)\end{array}$ & $\begin{array}{l}\text { Measured } \\
\text { density } \\
\left(\mathrm{g} \mathrm{cm}^{-3}\right)\end{array}$ & $\begin{array}{l}\text { Cell volume } \\
\left(10^{6} \mathrm{pm}^{3}\right)\end{array}$ & $\mathbf{Z}$ & $\begin{array}{l}\text { Space } \\
\text { group }\end{array}$ \\
\hline Bischofite & Monoclinic & 9.9000 & 7.1500 & 6.1000 & 90.0000 & 94.0000 & 90.0000 & - & 1.56 & 430.74 & 2 & n.a. \\
\hline $\mathrm{MgCl}_{2} \cdot 6 \mathrm{H}_{2} \mathrm{O}$ & Monoclinic & 9.8580 & 7.1070 & 6.0690 & 90.0000 & 93.0000 & 90.0000 & 1.591 & 1.593 & - & - & n.a. \\
\hline $\mathrm{Li}_{2} \mathrm{CO}_{3}$ & Monoclinic & 8.3600 & 4.9700 & 6.1900 & 90.0000 & 114.69 & 90.0000 & 2.10 & - & 234.1 & 4 & $\mathrm{C} 2 / \mathrm{C}$ \\
\hline $\mathrm{LiOH} \cdot \mathrm{H}_{2} \mathrm{O}$ & Monoclinic & 7.4153 & 8.3054 & 3.1950 & 90.0000 & 110.11 & 90.0000 & 1.51 & - & 184.78 & 4 & $\mathrm{C} 2 / \mathrm{C}$ \\
\hline $\mathrm{Sr}(\mathrm{OH})_{2}$ & Orthorhombic & 9.9800 & 6.1202 & 3.9184 & 90.0000 & 90.0000 & 90.0000 & 3.41 & & 257.15 & 4 & Pnam \\
\hline $\mathrm{SrCO} 3$ & Orthorhombic & 5.1000 & 8.4100 & 6.0300 & 90.0000 & 90.0000 & 90.0000 & 3.79 & 3.76 & 259.07 & 4 & Pmcn \\
\hline $\mathrm{CaO}$ & Cubic & 4.7780 & 4.778 & 4.7780 & 90.0000 & 90.0000 & 90.0000 & 3.41 & 3.30 & 109.08 & 4 & $\mathrm{~F} 23$ \\
\hline
\end{tabular}




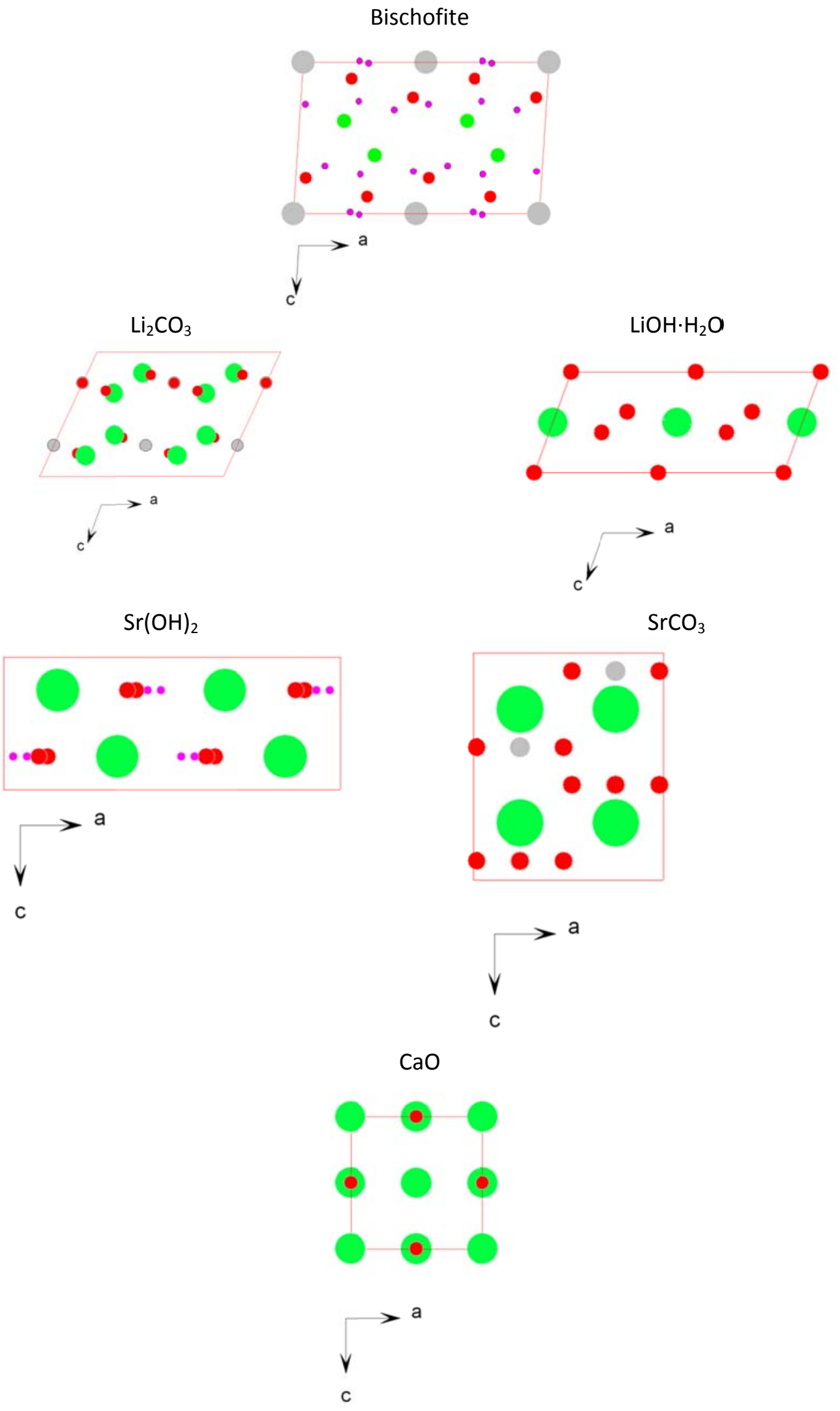

Figure 2. Unit cell of bischofite and nucleating agents tested 


\subsection{Reduction of bischofite subcooling by the addition of nucleating agents}

Based on DoE, eight mixtures of bischofite with each nucleating agent were performed in different percentage by weight composition. Results of thermal composition and reduction of subcooling obtained are show in Table 5. It can be seen that $\mathrm{LiOH} \cdot \mathrm{H}_{2} \mathrm{O}$ and $\mathrm{Li}_{2} \mathrm{CO}_{3}$ reduce the subcooling slightly from $36^{\circ} \mathrm{C}$ to $18^{\circ} \mathrm{C}$ (1\%wt.) and from $36^{\circ} \mathrm{C}$ to $18.8^{\circ} \mathrm{C}$ (1\%wt.) respectively. However they reduce significantly the values of enthalpy of fusion and crystallization, from $\Delta \mathrm{H}_{\mathrm{F}} 115.9 \mathrm{~kJ} \mathrm{~kg}^{-1}$ and $\Delta \mathrm{H}_{\mathrm{C}} 115.5$ $\mathrm{kJ} \mathrm{kg}^{-1}$ to $68.5 \mathrm{~kJ} \mathrm{~kg}^{-1}$ and $84.9 \mathrm{~kJ} \mathrm{~kg}^{-1}$ respectively with the addition of $\mathrm{LiOH} \cdot \mathrm{H} 2 \mathrm{O}$ (1\%wt.), and from $\Delta \mathrm{H}_{\mathrm{F}} 115.9 \mathrm{~kJ} \mathrm{~kg}^{-1}$ and $\Delta \mathrm{H}_{\mathrm{C}} 115.5 \mathrm{~kJ} \mathrm{~kg}^{-1}$ to $55.7 \mathrm{~kJ} \mathrm{~kg}^{-1}$ and $76.3 \mathrm{~kJ} \mathrm{~kg}^{-1}$ respectively with the addition of $\mathrm{Li}_{2} \mathrm{CO}_{3}$ (1\%wt). This is a disadvantage to apply these materials for thermal energy storage (TES), since the energy density of storage will be drastically reduced. A similar effect was observed by the addition of $\mathrm{CaO}$. The reduction of subcooling from $36^{\circ} \mathrm{C}$ to $11^{\circ} \mathrm{C}$ is possible by the addition of $3 \% \mathrm{wt}$ $\mathrm{CaO}$, but the enthalpy of fusion and crystallization is even more reduced than by the addition of lithium salts; from $115.9 \mathrm{~kJ} \mathrm{~kg}^{-1}$ and $115.5 \mathrm{~kJ}^{-1} \mathrm{~kg}$ to $28.7 \mathrm{~kJ} \mathrm{~kg}^{-1}$ and $28.5 \mathrm{~kJ} \mathrm{~kg}^{-1}$, respectively. Finally, the best results based on the reduction of subcooling were obtained by the addition of strontium salts. $\mathrm{Sr}(\mathrm{OH})_{2}$ and $\mathrm{SrCO}_{3}$ reduced subcooling from $36{ }^{\circ} \mathrm{C}$ to $-0.2{ }^{\circ} \mathrm{C}\left(3 \%\right.$ wt.) and $1.7{ }^{\circ} \mathrm{C}$ (3\%wt.), respectively. However, the enthalpy of fusion and crystallization are reduced, more significantly by the addition of $\mathrm{Sr}(\mathrm{OH})_{2}$ than by the addition of $\mathrm{SrCO}_{3}$. The first nucleating agent reduced these values from $115.9 \mathrm{~kJ} \mathrm{~kg}^{-1}$ and $115.5 \mathrm{~kJ} \mathrm{~kg}^{-1}$ to $90.3 \mathrm{~kJ} \mathrm{~kg}^{-1}$ and $71.1 \mathrm{~kJ} \mathrm{~kg}^{-1}$, but the addition of $3 \% \mathrm{wt}$. $\mathrm{SrCO}_{3}$ only reduced these properties to $\Delta \mathrm{H}_{\mathrm{F}}=109.7 \mathrm{~kJ} \mathrm{~kg}^{-1}$ and $\Delta \mathrm{H}_{\mathrm{C}}=89.3 \mathrm{~kJ} \mathrm{~kg}^{-1}$.

The curves of enthalpy vs. temperature are represented in Figure 3, for the mixture of bischofite + $3 \%$ wt. $\mathrm{Sr}(\mathrm{OH})_{2}$ and for the mixture of bischofite $+3 \% \mathrm{wt} . \mathrm{SrCO}_{3}$, which are the mixture with best results of subcooling reduction. In both cases the comparison for the curves of bischofite can be seen, and they reflect the results reported in Table 5. Enthalpies for both mixtures are lower than for bischofite without nucleating agents, but it can also be seen that the temperature of crystallization is almost the same as the melting point. 
Table 5. Thermophysical properties of bischofite, mixtures of bischofite with different nucleating agents and composition, and effect on the reduction of subcooling.

\begin{tabular}{|c|c|c|c|c|c|c|}
\hline Nucleating agent & wt.\% & $\mathrm{T}_{\mathrm{F}}\left[{ }^{\circ} \mathrm{C}\right]$ & $\Delta \mathrm{H}_{\mathrm{F}}[\mathrm{kJ} / \mathrm{kg}]$ & $\mathrm{T}_{\mathrm{C}}\left[{ }^{\circ} \mathrm{C}\right]$ & $\Delta \mathrm{H}_{\mathrm{C}}[\mathrm{kJ} / \mathrm{kg}]$ & $\Delta \mathrm{T}\left[{ }^{\circ} \mathrm{C}\right]$ \\
\hline Only Bischofite & 0 & 101.4 & 115.9 & 65.4 & 115.5 & 36 \\
\hline \multirow{5}{*}{$\mathrm{CaO}$} & 0.5 & 104.6 & 96.2 & 88.2 & 95.3 & 16.3 \\
\hline & 1 & 98.7 & 47.5 & 78.8 & 57.0 & 19.9 \\
\hline & 1.5 & 96.7 & 40.5 & 75.2 & 50.8 & 21.4 \\
\hline & 2 & 84.0 & 16.2 & 86.1 & 46.6 & 20.4 \\
\hline & 3 & 88.4 & 28.7 & 77.4 & 28.5 & 11.0 \\
\hline \multirow{5}{*}{$\mathrm{Sr}(\mathrm{OH})_{2}$} & 0.5 & 105.6 & 91.1 & 87.4 & 104.4 & 18.2 \\
\hline & 1 & 104.1 & 57.1 & 101.2 & 36.6 & 2.9 \\
\hline & 1.5 & 101.1 & 53.9 & 81.9 & 73.1 & 20.4 \\
\hline & 2 & 103.5 & 60.4 & 84.1 & 78.6 & 18.7 \\
\hline & 3 & 105.7 & 90.3 & 105.9 & 71.1 & -0.2 \\
\hline \multirow{5}{*}{$\mathrm{SrCO}_{3}$} & 0.5 & 110.5 & 104.1 & 86.8 & 118.8 & 23.7 \\
\hline & 1 & 107.0 & 86.56 & 84.5 & 106.8 & 22.4 \\
\hline & 1.5 & 104.5 & 75.7 & 89.2 & 92.3 & 15.7 \\
\hline & 2 & 91.8 & 78.61 & 86.3 & 94.5 & 5.51 \\
\hline & 3 & 107.5 & 109.7 & 105.8 & 89.3 & 1.7 \\
\hline \multirow{5}{*}{$\mathrm{LiOH} \cdot \mathrm{H}_{2} \mathrm{O}$} & 0.5 & 104.5 & 89.9 & 80.3 & 99.7 & 24.2 \\
\hline & 1 & 101.2 & 68.5 & 93.2 & 84.9 & 18.0 \\
\hline & 1.5 & 98.9 & 61.0 & 77 & 82.7 & 21.9 \\
\hline & 2 & 97.7 & 57.2 & 74.1 & 85.6 & 23.6 \\
\hline & 3 & 90.5 & 22.2 & 72.2 & 63.5 & 18.3 \\
\hline \multirow{5}{*}{$\mathrm{Li}_{2} \mathrm{CO}_{3}$} & 0.5 & 106 & 118.3 & 78.1 & 85.9 & 27.8 \\
\hline & 1 & 99.5 & 55.7 & 80.7 & 76.3 & 18.8 \\
\hline & 1.5 & 98.9 & 51.0 & 76.9 & 76.3 & 22.0 \\
\hline & 2 & 95.3 & 35.5 & 76.1 & 64.1 & 19.1 \\
\hline & 3 & 100.8 & 25.8 & 75.2 & 59.9 & 25.6 \\
\hline
\end{tabular}

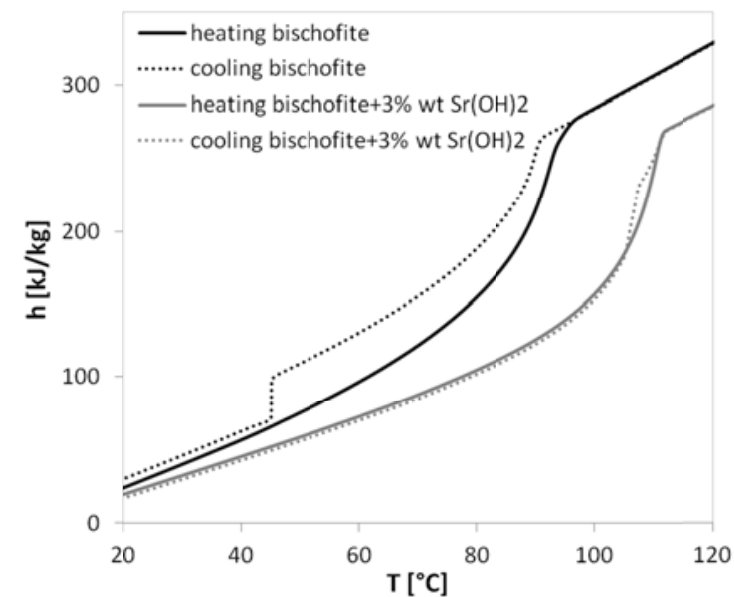

(a)

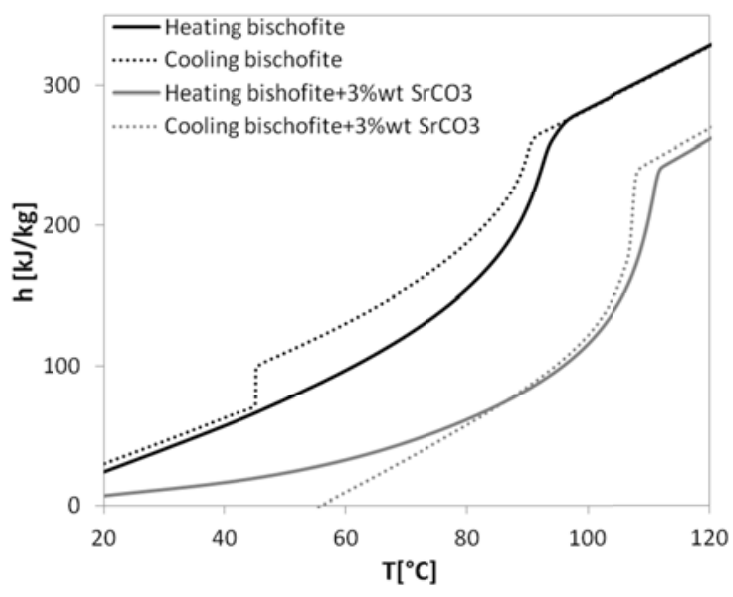

(b)

Figure 3. Curves of enthalpies of one cycle of heating and cooling for bischofite and mixtures of bischofite with nucleating agents. (a) Bischofite $+3 \% w t . \mathrm{Sr}(\mathrm{OH})_{2}$; and (b) Bischofite $+3 \% w t \mathrm{SrCO}_{3}$. 
In agreement with the described results, design of experiments elucidate that the addition of $\mathrm{CaO}$ is not statistically significant to reduce the subcooling while $\mathrm{Sr}(\mathrm{OH})_{2}, \mathrm{SrCO}_{3}, \mathrm{LiOH} \cdot \mathrm{H}_{2} \mathrm{O}, \mathrm{Li}_{2} \mathrm{CO}_{3}$ are statistically significant able to reduce the subcooling of Bischofite several degrees Celsius following the next statistically obtained equations (Eq.1 - Eq. 4) which can be used to make predictions regarding the Bischofite subcooling when one of these agents are used as nucleating agent. All the predictions made following these equations will have $95 \%$ confidence.

$\begin{array}{lcc}\mathrm{Sr}(\mathrm{OH})_{2} & \Delta \mathrm{T}_{\text {subcooling }}=52.25-105.24 \cdot \mathrm{NA}+76.75 \cdot \mathrm{NA}^{2}-15.85 \cdot \mathrm{NA}^{3} & \text { Eq. (1) } \\ \mathrm{SrCO}_{3} & \Delta \mathrm{T}_{\text {subcooling }}=29.58-9.86 \cdot \mathrm{NA} & \text { Eq. (2) } \\ \mathrm{LiOH} & \Delta \mathrm{T}_{\text {subcooling }}=40.35-47.41 \cdot \mathrm{NA}+32.24 \cdot \mathrm{NA}^{2}-6.33 \cdot \mathrm{NA}^{3} & \text { Eq. (3) } \\ \mathrm{LiCO}_{3} & \Delta \mathrm{T}_{\text {subcooling }}=33.44-15.92 \cdot \mathrm{NA}+4.45 \cdot \mathrm{NA}^{2} & \text { Eq. (4) } \\ \mathrm{NA}-\text { nucleating agent } & & \end{array}$

\section{Discussion}

Table 6 summarizes the results of the experimentation. The summary of results is:

- $\mathrm{CaO}$ did reduce the subcooling of bischofite partially, but at the same time did reduce very much the melting enthalpy. Moreover, its addition to bischofite as nucleating agent does not affect statistically subcooling. $\mathrm{CaO}$ has the most different crystal structure to bischofite (Figure 2).

- $\mathrm{LiOH} \cdot \mathrm{H}_{2} \mathrm{O}$ and $\mathrm{Li}_{2} \mathrm{CO}_{3}$ did not reduce the subcooling of bischofite. They both have the same crystal structure as bischofite, but different lattice parameters. Their presence did affect statistically subcooling and can be predicted with Eq. 3 and 4, respectively.

- $\operatorname{Sr}(\mathrm{OH})_{2}$ and $\mathrm{SrCO}_{3}$ did reduce significally the subcooling without affecting the melting enthalpy, so they act as good nucleating agents for bischofite. They have different chemical and crystal structure to bischofite, but their lattice parameters are the most similar, having the same three angles. Their presence did affect statistically subcooling and can be predicted with Eq. 1 and 2, respectively.

The chemical structure of bischofite and the considered nucleation agents is compared considering the anion ( $\mathrm{A}$ : compared to $\mathrm{Mg}$ ), the cation ( $\mathrm{C}$ : compared to $\mathrm{Cl}$ ) and the presence of hydration water (W) (see Table 6). All considered nucleation agents have similarity only in one of those parameters, either the cation, the anion or the presence of hydration water, therefore, this parameter has no influence in the nucleation capacity.

Similarly, the solubility of the products with water has no influence in the nucleation capacity. The materials studied have either similar solubility $\left(\mathrm{LiOH} \cdot \mathrm{H}_{2} \mathrm{O}\right.$ ) or very similar (all other nucleation agents considered are not soluble in water). No correlation can be found between this parameter and the nucleation capacity of the products considered. 
As mentioned before, the crystal structure has been listed as one of the most important parameters to select the adequate nucleation agent. These experiments show that this parameter does not ensure nucleation of PCM.

Finally, the lattice parameters (cell longitude or angle) are the parameters that should be considered to choose the adequate nucleating agent. 
Table 6. Summary of results

\begin{tabular}{|c|c|c|c|c|c|c|}
\hline Parameter & Bischofite & $\mathrm{CaO}$ & $\mathrm{Sr}(\mathrm{OH})_{2}$ & $\mathrm{SrCO}_{3}$ & $\mathrm{LiOH} \cdot \mathrm{H}_{2} \mathrm{O}$ & $\mathrm{Li}_{2} \mathrm{CO}_{3}$ \\
\hline $\begin{array}{l}\text { Chemical Structure (similar to } \\
\mathrm{MgCl}_{2} \cdot 6 \mathrm{H}_{2} \mathrm{O} \text { ) } \\
\mathrm{Mg}: \mathrm{A} \\
\mathrm{Cl}: \mathrm{C} \\
\mathrm{H}_{2} \mathrm{O}: \mathrm{W}\end{array}$ & $\begin{array}{l}\text { A: Yes } \\
\text { C: Yes } \\
\text { W: Yes }\end{array}$ & $\begin{array}{l}\text { A: Yes } \\
\text { C: No } \\
\text { W: No }\end{array}$ & $\begin{array}{l}\text { A: Yes } \\
\text { C: No } \\
\text { W: No }\end{array}$ & $\begin{array}{l}\text { A: Yes } \\
\text { C: No } \\
\text { W: No }\end{array}$ & $\begin{array}{l}\text { A: No } \\
\text { C: No } \\
\text { W: Yes }\end{array}$ & $\begin{array}{l}\text { A: No } \\
\text { C: No } \\
\text { W: No }\end{array}$ \\
\hline Crystal structure & Monoclinic & Cubic & Orthorhombic & Orthorhombic & Monoclinic & Monoclinic \\
\hline $\begin{array}{l}\text { Lattice Parameters (similar to } \\
\mathrm{MgCl}_{2} \cdot 6 \mathrm{H}_{2} \mathrm{O} \text { ) }\end{array}$ & $\begin{array}{l}\text { Long: } 3 / 3 \\
\text { Angle: } 3 / 3\end{array}$ & $\begin{array}{l}\text { Long: } 1 / 3 \\
\text { Angle: } 3 / 3\end{array}$ & $\begin{array}{l}\text { Long: } 1 / 3 \\
\text { Angle: } 3 / 3\end{array}$ & $\begin{array}{l}\text { Long: } 2 / 3 \\
\text { Angle: } 3 / 3\end{array}$ & $\begin{array}{l}\text { Long: } 1 / 3 \\
\text { Angle: } 2 / 3\end{array}$ & $\begin{array}{l}\text { Long: } 1 / 3 \\
\text { Angle: } 2 / 3\end{array}$ \\
\hline $\begin{array}{l}\text { Solubility (mole (100 g } \\
\text { dissolution) })^{-1} \text { ) }\end{array}$ & $\approx 0.37-0.40$ & 0 & $\approx 0.05-0.20$ & 0 & $\approx 0.42-0.58$ & $\approx 0.03$ \\
\hline Subcooling $\left({ }^{\circ} \mathrm{C}\right)$ & 36 & $11^{(3 \% \mathrm{wt} \mathrm{CaO})_{*}}$ & $-0.2^{(3 \% \text { wt Sr(OH)2)* }}$ & $1.7^{(3 \% \text { wt SrCO3) }}$ & $18.0^{(1 \% \text { wt LiOH·H2O })_{*}}$ & $18.8^{(1 \% \text { wt Li2CO3) } *}$ \\
\hline Enthalpy of fusion (kJ/kg) & 115.9 & 28.7 & 90.3 & 109.7 & 68.5 & 55.7 \\
\hline Enthalpy of crystallization $(\mathrm{kJ} / \mathrm{kg})$ & 115.5 & 28.5 & 71.1 & 89.3 & 84.9 & 76.3 \\
\hline
\end{tabular}

*Subcooling decrease statistically significant (95\% confidence) 


\section{Conclusions}

Salt hydrates present subcooling when used as phase change materials (PCM). In the case of bischofite, a by-product from the Chilean non-metallic industry, subcooling is about 36 으, too high for its use in real applications. Subcooling can be reduced by the addition of nucleating agents. The selection of the best nucleating agent should be done taking into consideration the physical and chemical parameters of the salt hydrate, but they are not clearly indicated in the literature.

In this paper different parameters and properties have been considered. The factors considered were the solubility of the materials in water, the chemical structure and the crystalline structure (crystal system, lattice parameters, density, cell volume, Z, and space group).

A first selection of nucleating agents was done based in literature data and then chemical and physical analyses of these materials were determined. Furthermore, $1 \%$ to $3 \%$ of nucleating agent was added to the considered PCM, bischofite, and the subcooling reduction was calculated.

As conclusion, it can be seen that the parameter that needs to be considered when selecting a nucleating agent for a salt hydrate are the lattice parameters of the crystal structure (cell longitude or angle). Solubility, chemical structure and the crystal structure have no influence in the nucleation capacity of a salt hydrate.

\section{Acknowledgements}

The work is partially funded by the Spanish government (ENE2011-28269-C03-02, ENE2011-22722). The authors would like to thank the Catalan Government for the quality accreditation given to their research group GREA (2014 SGR 123) and research group DIOPMA (2014 SGR 1543). This project has received funding from the European Commission Seventh Framework Programme (FP/2007-2013) under Grant agreement №PIRSES-GA-2013-610692 (INNOSTORAGE) and from the European Union's Horizon 2020 research and innovation programme under grant agreement No 657466 (INPATH-TES).

\section{References}

1. Ushak S, Gutierrez A, Galleguillos H, Fernandez AG, Cabeza LF, Grágeda M. Thermophysical characterization of a by-product from the non-metallic industry as inorganic PCM. Solar Energy Materials \& Solar Cells 132 (2015) 385-391.

2. Gutierrez A, Miro L, Gil A, Rodriguez-Aseguinolaza J, Barreneche C, Calvet N, Py X, Fernandez Al, Grageda M, Ushak S, Cabeza LF. Advances in the valorization of waste and by-product materials as thermal energy storage (TES) materials. Renewable and Sustainable Energy Reviews, 2015, in press.

3. Huang L, Günther E, Doetsch C, Mehling H. Subcooling in PCM emulsions - Part 1: Experimental. Thermochimica Acta 509 (2010) 93-99.

4. Cabeza LF, Castell A, Barreneche C, de Gracia A, Fernandez Al. Materials used as PCM in thermal energy storage in buildings: A review. Renewable and Sustainable Energy Reviews 15 (2011) 1675-1695.

5. Lane GA. Phase change materials for energy storage nucleation to prevent supercooling. Solar Energy Mater. Solar Cells 27 (1992) 135-160. 
6. Pilar R, Svoboda L, Honcova P, Oravova L. Study of magnesium chloride hexahydrate as heat storage material. Thermochimica Acta 546 (2012) 81-86.

7. Günther E, Schmid G, Mehling H, Hiebler S, Huang L. Subcooling in hexadecane emulsions. International journal of refrigeration 33 (2010) 1605-1611.

8. Murr LE. Solar materials science, Elsevier, 2012, UK. ISBN: 0-12-511160-6

9. Young D. High temperature oxidation and corrosion of metals. Elsevier, 2008, UK. ISBN: 978-008-044587-8

10. Agron PA, Busing WR. Magnesium dichloride hexahydrate, $\mathrm{MgCl}_{2}{ }^{*} 6 \mathrm{H}_{2} \mathrm{O}$. Acta Crystallographica C41 (1985) 8-10.

11. Martin K, McCarthy G. North Dakota State University, Fargo, North Dakota, USA, ICDD Grant-inAid (1992).

12. Petch HE. The hydrogen positions in portlandite, $\mathrm{Ca}(\mathrm{OH})_{2}$, as indicated by the electron distribution. Acta Crystallogy 14 (1961) 950-957.

13. Zemann J. Die Kristallstruktur von $\mathrm{Li}_{2} \mathrm{CO}_{3}$. Acta Crystallogy 10 (1957) 664-666.

14. Mallard, E. Bull. Soc. Fr. Mineral Cristallogy 15 (1892) 21-26.

15. Hanawalt JD, Rinn HW, Fervel LK. Chemical Analysis by X-Ray Diffraction. Anal Chem 10 (1938) 475-512.

16. Effenberger $\mathrm{H}$, Zemann J. Refining the Crystal-Structure of Lithium-Structure of LithiumCarbonate, $\mathrm{Li}_{2} \mathrm{CO}_{3}$. Z. Krisallogy 150 (1979) 133-138.

17. Hermansson $\mathrm{K}$, Lunell $\mathrm{S}$. The theoretical electron density in lithium hydroxide monohydrate. Acta Cryst.B38 (1982) 2555-2569.

18. Baernighausen H, Beck H, Grueninger H, Rietschel E, Schultz N. 128 (1969) 431.

19. De Villiers JPR. Crystal Structures of Aragonite, Strontianite, and Witherite. Am Mineral 56 (1971) 758-767.

20. Stromme KO. On the Crystal Structures of the High-temperature Forms of Strontium and Barium Carbonate and Structurally Related Compounds. Acta Chem Scand Ser A. 29 (1975) 105-110.

21. Jarosch D, Heger G. Neutron diffraction investigation of strontianite, $\mathrm{SrCO}_{3}$. Bull Mineral 111 (1988) 139-142.

22. Pannhorst W, Löhn J. Zur kristallstruktur von strontianit, $\mathrm{SrCO}_{3}$. Z. Kristallogr. 131 (1970) 455459.

23. Fiquet $G$, Richet $P$, Montagnac $G$. High-temperature thermal expansion of lime, periclase, corundum and spinel. Physics and Chemistry of Minerals 27 (1999) 103-111.

24. Primak W, Kaufman H, Ward R. X-Ray Diffraction Studies of Systems Involved in the Preparation of Alkaline Earth Sulfide and Selenide Phosphors. J. Am. Chem Soc 70 (1948) 2043-2046.

25. Villars P. Material Phases Data System (MPDS), CH-6354 Vitznau, Switzerland; SpringerMaterials; sd_1932149 (Springer-Verlag GmbH, Heidelberg, 2014),

http://materials.springer.com/isp/crystallographic/docs/sd_1932149; accessed: 19-06-2015.

26. Linke WF, Seidell A. Solubilities inorganic and metal organic compounds. New York, D. Van Nostrand Company, 1965.

27. Diamond. Crystal and Molecular Structure Visualization. http://www.crystalimpact.com/diamond/; accessed: 19-06-2015

28. Romero R, Zunica L. (1993). Estadística, diseño de experimento y modelos de regresión. Universidad Politécnica de Valencia, Valencia, Spain. ISBN: 8477212236

29. Oró E, Barreneche C, Farid M.M, Cabeza LF. Experimental study on the selection of phase change materials for low temperature applications. Renewable Energy 57 (2013) 130-136. 